\title{
Rheinheimera pacifica sp. nov., a novel halotolerant bacterium isolated from deep sea water of the Pacific
}

\author{
Lyudmila A. Romanenko, ${ }^{1}$ Masataka Uchino, ${ }^{2}$ Enevold Falsen, ${ }^{3}$ \\ Natalia V. Zhukova, ${ }^{4}$ Valery V. Mikhailov ${ }^{1}$ and Tai Uchimura ${ }^{2}$ \\ ${ }^{1}$ Pacific Institute of Bioorganic Chemistry, Far-Eastern Branch, Russian Academy of Sciences, \\ 690022 Vladivostok, Prospect 100 Let Vladivostoku, 159, Russia
${ }^{2}$ Laboratory of Food Science and Technology, Department of Applied Biology and Chemistry, Tokyo 156-8502, Japan
${ }^{3}$ Culture Collection, Department of Clinical Bacteriology, University of Göteborg, Göteborg, Sweden
${ }^{4}$ Institute of Marine Biology, Far-Eastern Branch, Russian Academy of Sciences, 690041 , Vladivostok, Russia \\ Faculty of Applied Bioscience, Tokyo University of Agriculture, Sakuragaoka 1-1-1, Setagaya-ku,
}

Lyudmila A. Romanenko piboc@stl.ru

\begin{abstract}
An aerobic, Gram-negative, non-fermentative, rod-shaped, motile, non-pigmented bacterium, KMM $1406^{\top}$, was isolated from a sample of Pacific deep sea water and investigated for phenotypic characteristics, chemotaxonomic features and phylogenetic relationships. The deep-sea isolate exhibited growth in $0-8 \%(\mathrm{w} / \mathrm{v}) \mathrm{NaCl}$ and at $4-37^{\circ} \mathrm{C}$, hydrolytic activity on gelatin, Tween 80 and starch and lack of $D$-glucose utilization. The major fatty acids were $C_{16: 0}, C_{16: 1} \omega 9 c, C_{17: 1} \omega 8 c$ and $\mathrm{C}_{18: 1} \omega 7 \mathrm{c}$. The DNA G $+\mathrm{C}$ content was 49.6 mol\%. $16 \mathrm{~S}$ rRNA gene sequence analysis revealed that strain $\mathrm{KMM} 1406^{\top}$ was related closely to Rheinheimera baltica DSM $14885^{\top}$ within the $\gamma$-Proteobacteria, with $96.8 \%$ sequence similarity. On the basis of phenotypic and molecular data, a novel species, Rheinheimera pacifica sp. nov., is proposed. The type strain is KMM $1406^{\top}\left(=\right.$ IAM $15043^{\top}=J_{C M} 12090^{\top}=$ NRIC $0539^{\top}=$ CCUG $\left.46544^{\top}\right)$.
\end{abstract}

Gram-negative, aerobic, heterotrophic, non-fermentative bacteria that are associated with marine habitats belong to different genera within the $\gamma$-Proteobacteria. Among them, the recently described genus Rheinheimera, which currently comprises a single species, Rheinheimera baltica DSM $14885^{\mathrm{T}}$, was proposed for motile, blue-coloured, nonhalotolerant bacteria isolated from Baltic sea-water samples (Brettar et al., 2002). Phylogenetic relatives of $R$. baltica DSM $14885^{\mathrm{T}}$ were a clinical isolate of Alishewanella fetalis (Fonnesbech Vogel et al., 2000) with sequence similarity of $94 \cdot 8 \%$ and, more closely related $(96 \cdot 5-96 \cdot 8 \%$ sequence similarity), some deep-sea bacteria that were reported by Takami et al. (1999) (Brettar et al., 2002). During the course of studying biodiversity of deep-sea micro-organisms of the Pacific, we isolated the motile, non-pigmented, halotolerant bacterium KMM $1406^{\mathrm{T}}$ and characterized it by using polyphasic taxonomy. Several phenotypic and physiological properties of the new deep-sea isolate were consistent with those of $R$. baltica. 16S rRNA gene sequence analysis

Abbreviation: PNPG, $p$-nitrophenyl $\alpha$-D-glucopyranoside.

The GenBank/EMBL/DDBJ accession number for the $16 \mathrm{~S}$ rDNA sequence of $\mathrm{KMM} 1406^{\top}$ is $\mathrm{AB} 073132$. confirmed the affiliation of strain KMM $1406^{\mathrm{T}}$ to the genus Rheinheimera. Sequence similarity with its close phylogenetic relative, $R$. baltica DSM $14885^{\mathrm{T}}$, was $96 \cdot 8 \%$. Based on phenotypic features and genetic analysis, we concluded that strain KMM $1406^{\mathrm{T}}$ represents a novel species within the genus Rheinheimera, for which the name Rheinheimera pacifica sp. nov. is proposed.

Strain KMM $1406^{\mathrm{T}}$ was isolated from a sea-water sample that was obtained from a depth of $5000 \mathrm{~m}$ in the northwestern part of the Pacific Ocean in July 1985. The sea-water sample was taken by a plastic hydrological bathometer. Aliquots $(100 \mu \mathrm{l})$ of sea water were spread onto agar plates of sea-water medium (SWM) that contained $\left(1^{-1}\right): 5 \cdot 0 \mathrm{~g}$ peptone, $2 \cdot 5 \mathrm{~g}$ yeast extract, $1.0 \mathrm{~g}$ glucose, $0 \cdot 2 \mathrm{~g} \mathrm{~K} \mathrm{HPO}_{4}$, $0.05 \mathrm{~g} \mathrm{MgSO}_{4}, 750 \mathrm{ml}$ sea water, $250 \mathrm{ml}$ distilled water and $15.0 \mathrm{~g}$ agar. Inoculated plates were incubated for 10 days at $28^{\circ} \mathrm{C}$. The bacterium was cultivated aerobically on marine agar 2216 (MA), marine broth (MB; Difco) or tryptic soy agar (TSA) at $25-28{ }^{\circ} \mathrm{C}$ and stored at $-80^{\circ} \mathrm{C}$ in liquid medium supplemented with $30 \%(\mathrm{v} / \mathrm{v})$ glycerol. Strain KMM $1406^{\mathrm{T}}$ has been deposited in the Collection of Marine Microorganisms (KMM) of the Pacific Institute of 
Bioorganic Chemistry, Vladivostok, Russia. The type strains of Rheinheimera baltica (DSM $14885^{\mathrm{T}}$ ) and Alishewanella fetalis (CCUG $30811^{\mathrm{T}}$ ) were used in this study for comparison. Cell morphology was examined with a phase-contrast microscope. Motility was observed by the hanging-drop method. Cell morphology was examined by transmission electron microscopy on exponential-phase cells that were grown in TSB. Cells were negatively stained with potassium phosphotungstate $(1 \%$, w/v; $\mathrm{pH} 7 \cdot 0)$. Gram-reaction, oxidase and catalase activity, nitrate reduction and production of caseinase, deoxyribonuclease, gelatinase and lipase (Tween 80) were tested according to standard methods described by Smibert \& Krieg (1994). Hydrolysis of starch was determined after 2 days incubation on nutrient agar medium that contained $10 \%(\mathrm{w} / \mathrm{v})$ soluble starch by flooding plates with $1 \%(\mathrm{w} / \mathrm{v})$ iodine solution. Formation of $\mathrm{H}_{2} \mathrm{~S}$ from thiosulfate was detected with lead acetate paper. Ability to grow at different temperatures was tested on MA and TSA at 4, 10, 15, 25, 30, 35, 37 and $42^{\circ} \mathrm{C}$. The $\mathrm{pH}$ range for growth $(5 \cdot 0-10 \cdot 0)$ was tested by using $\mathrm{MB}$ with $\mathrm{pH}$ values adjusted by addition of $5 \mathrm{M} \mathrm{NaOH}$ or $\mathrm{HCl}$. Sodium ion requirement and tolerance of various $\mathrm{NaCl}$ concentrations were examined by using SWM prepared with artificial sea water with $\mathrm{NaCl}$ concentrations of 0,1 , $3,5,8,10,12,15$ and $20 \%(\mathrm{w} / \mathrm{v})$. The strain was tested for its ability to ferment glucose and produce acid from carbohydrates with a supplement of $1 \%(w / v)$ of each compound by the use of marine oxidation-fermentation medium (Leifson, 1963). The ability to utilize various compounds as sole carbon and energy sources was examined in a mineral liquid medium that contained $\left(\mathrm{g} \mathrm{l}^{-1}\right)$ : $\mathrm{NH}_{4} \mathrm{Cl}, 1 \cdot 0 ; \mathrm{K}_{2} \mathrm{HPO}_{4}, 0 \cdot 075 ; \mathrm{CaCl}_{2}, 1 \cdot 45 ; \mathrm{NaCl}, 5 \cdot 0 ; \mathrm{MgCl}_{2}$, $6 \cdot 15 ; \mathrm{KCl}, 0 \cdot 75$; and $\mathrm{FeSO}_{4}, 0 \cdot 028$, supplemented with $0 \cdot 2 \%(\mathrm{w} / \mathrm{v})$ of one of the test substrates. Bacterial growth was determined spectrophotometrically after 2 days cultivation. Strain KMM $1406^{\mathrm{T}}$ was characterized additionally by using API 20NE and API ZYM identification systems (bioMérieux) at $28^{\circ} \mathrm{C}$. Antibiotic sensitivity was tested by the agar-diffusion method on TSA plates by using discs impregnated with antibiotics (content per disc): ampicillin, $10 \mu \mathrm{g}$; benzylpenicillin, $10 \mathrm{U}$; gentamicin, $10 \mu \mathrm{g}$; kanamycin, $30 \mu \mathrm{g}$; carbenicillin, $25 \mu \mathrm{g}$; lincomycin, $15 \mu \mathrm{g}$; oleandomycin, $15 \mu \mathrm{g}$; polymyxin, $300 \mathrm{U}$; streptomycin, $30 \mu \mathrm{g}$; tetracycline, $30 \mu \mathrm{g}$; and neomycin, $15 \mu \mathrm{g}$. DNA base composition was determined as described by Marmur \& Doty (1962) and Owen et al. (1969). Whole-cell fatty acids were determined as described by Svetashev et al. (1995). 16S rRNA gene sequences were determined and compared as described by Shida et al. (1997). Previously published 16S rRNA gene sequences were obtained from GenBank/EMBL/DDBJ.

Deep-sea isolate KMM $1406^{\mathrm{T}}$ was an aerobic, Gramnegative, oxidase- and catalase-positive, chemoheterotrophic, non-pigmented, rod-shaped bacterium that measured $0 \cdot 6-0 \cdot 8 \mu \mathrm{m}$ in diameter and $1 \cdot 8-2 \cdot 0 \mu \mathrm{m}$ in length. Cells were motile by means of four to seven polar or bipolar and lateral flagella (Fig. 1). Strain KMM $1406^{\mathrm{T}}$ did not require

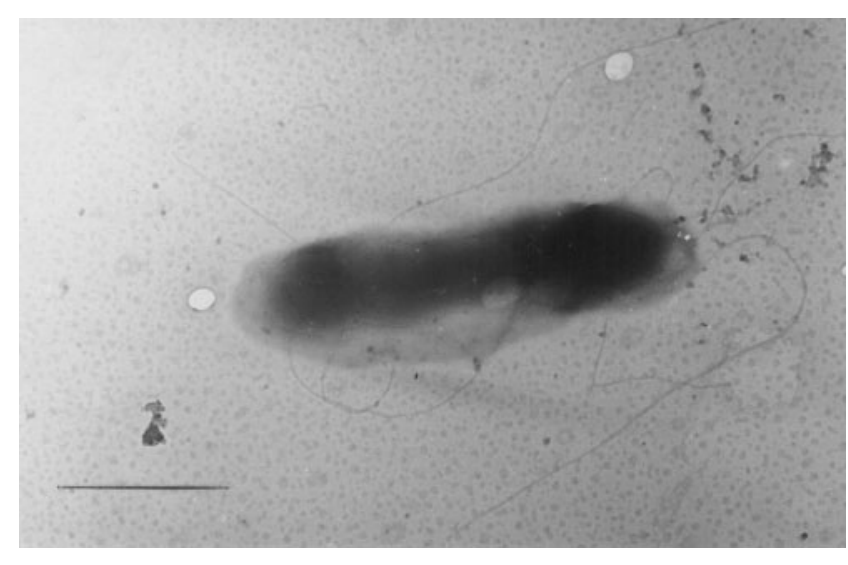

Fig. 1. Electron micrograph of a negatively stained cell of KMM $1406^{\top}$. Bar, $1 \mu \mathrm{m}$.

sodium ions for growth and grew in $0-8 \%(\mathrm{w} / \mathrm{v}) \mathrm{NaCl}$. Growth temperature was $4-37^{\circ} \mathrm{C}$. No growth was observed in $10 \% \mathrm{NaCl}$ or at 40 or $41^{\circ} \mathrm{C}$. The new bacterium formed non-pigmented, smooth, transparent, shining, convex and circular colonies with entire margins that were $3-5 \mathrm{~mm}$ in diameter on TSA and MA after $24 \mathrm{~h}$ incubation and released a slightly brown diffusible pigment into the medium. Strain KMM $1406^{\mathrm{T}}$ was unable to produce acid from carbohydrates aerobically or to ferment glucose under anaerobic conditions. Hydrolytic reactions on starch, gelatin and casein were observed after $24 \mathrm{~h}$, but Tween 80 and DNA were hydrolysed after 3 days incubation. Other phenotypic characteristics of strain KMM $1406^{\mathrm{T}}$ are shown in Table 1.

Major fatty acids of strain $\mathrm{KMM} 1406^{\mathrm{T}}$ were $\mathrm{C}_{16: 1} \omega 9 \mathrm{c}$ $(25 \cdot 5 \%), \mathrm{C}_{16: 0}(19 \cdot 1 \%), \mathrm{C}_{18: 1} \omega 7 c(15 \cdot 7 \%), \mathrm{C}_{17: 0}(8 \cdot 1 \%)$ and $\mathrm{C}_{17: 1} \omega 8 c(11 \cdot 7 \%)$; fatty acids $\mathrm{C}_{15: 0}(2 \cdot 4 \%), \mathrm{C}_{15: 1} \omega 8 c$ $(3 \cdot 3 \%), \mathrm{i}-\mathrm{C}_{16: 0}(3 \cdot 7 \%)$ and $\mathrm{i}-\mathrm{C}_{18: 0}(1 \cdot 3 \%)$ were detected as minor components. The DNA G $+\mathrm{C}$ content of strain KMM $1406^{\mathrm{T}}$ was $49 \cdot 6 \mathrm{~mol} \%$.

Phylogenetic relationships among strain KMM $1406^{\mathrm{T}}$ and some related taxa are shown in Fig. 2. Comparative 16S rRNA gene sequence analysis showed that the new isolate was phylogenetically most closely related to $R$. baltica DSM $14885^{\mathrm{T}}$ and deep-sea isolates HBT 019, HTB 010 and HTB 021 (Takami et al., 1999), with $96 \cdot 8-97 \cdot 4 \%$ sequence similarity, and less closely related to A. fetalis CCUG $30811^{\mathrm{T}}$ (Fonnesbech Vogel et al., 2000), with $95 \cdot 4 \%$ sequence similarity. This $16 \mathrm{~S}$ rDNA sequence similarity value with $R$. baltica DSM $14885^{\mathrm{T}}$ is appropriate for determining intrageneric relationships for species definition (Stackebrandt \& Goebel, 1994), indicating that strain KMM $1406^{\mathrm{T}}$ probably represents a novel species within the genus Rheinheimera. The novel deep-sea isolate shared main physiological characteristics, assimilation pattern and spectrum of enzyme activities with $R$. baltica DSM $14885^{\mathrm{T}}$. Its DNA G $+C$ content was close to those of $R$. baltica strains $(47 \cdot 8-48 \cdot 9 \mathrm{~mol} \%)$. The fatty acid profiles of KMM $1406^{\mathrm{T}}$ 
Table 1. Phenotypic characteristics of strain $\mathrm{KMM} 1406^{\top}$ and the related bacteria Rheinheimera baltica DSM $14885^{\top}$ and Alishewanella fetalis CCUG $30811^{\top}$

Taxa: 1, KMM $1406^{\mathrm{T}}$; 2, Rheinheimera baltica DSM $14885^{\mathrm{T}}$; 3, Alishewanella fetalis CCUG $30811^{\mathrm{T}}$. +, Positive; -, negative; W, weak reaction; ND, not determined; NG, no growth. Data are from Brettar et al. (2002), Fonnesbech Vogel et al. (2000) and the present study. All strains are Gram-negative, positive for oxidase, catalase, gelatinase and growth in $3 \% \mathrm{NaCl}$ and negative for growth in $10 \% \mathrm{NaCl}$, arginine dihydrolase and urease activities, acid production from D-glucose and mannitol and assimilation of D-mannose, caprate, adipate, L-malate, phenylacetate and gluconate.

\begin{tabular}{|c|c|c|c|}
\hline Feature & 1 & 2 & 3 \\
\hline Pigmentation & - & + & - \\
\hline Motility & + & + & - \\
\hline \multicolumn{4}{|l|}{ Flagella arrangement: } \\
\hline Polar & + & + & - \\
\hline Bipolar, lateral & + & - & - \\
\hline \multicolumn{4}{|l|}{ Growth at $\left({ }^{\circ} \mathrm{C}\right)$ : } \\
\hline 4 & + & + & - \\
\hline 25 & + & + & $\mathrm{W}$ \\
\hline 37 & + & - & + \\
\hline $40-42$ & - & - & + \\
\hline \multicolumn{4}{|l|}{ Growth in $\mathrm{NaCl}(\%)$ : } \\
\hline 0 & + & $+^{*}$ & - \\
\hline 6 & + & - & + \\
\hline 8 & + & - & + \\
\hline \multicolumn{4}{|l|}{ Hydrolysis of: } \\
\hline Tween 80 & + & + & + \\
\hline Starch & + & + & - \\
\hline DNA & + & $\mathrm{ND}$ & NG \\
\hline \multicolumn{4}{|l|}{ API test: } \\
\hline Nitrate reduction & - & - & + \\
\hline Aesculin hydrolysis & + & - & + \\
\hline \multicolumn{4}{|l|}{ Utilization of: } \\
\hline Glucose & - & + & - \\
\hline L-Arabinose & + & - & - \\
\hline$N$-Acetylglucosamine & + & + & - \\
\hline Maltose & + & + & $\mathrm{W}$ \\
\hline Citrate & + & - & - \\
\hline DNA G + C content $(\mathrm{mol} \%)$ & $49 \cdot 6$ & $48 \cdot 9$ & $50 \cdot 6$ \\
\hline Isolation source & Pacific deep sea water & Baltic surface sea water & Human foetus \\
\hline
\end{tabular}

${ }^{*}$ In the present study, $R$. baltica DSM $14885^{\mathrm{T}}$ did not grow without $\mathrm{NaCl}$.

and R. baltica (Brettar et al., 2002) were found to be similar to each other, but strain $\mathrm{KMM} 1406^{\mathrm{T}}$ contained a higher proportion of $\mathrm{C}_{17: 0}$ and $\mathrm{C}_{17: 1} \omega 8 c$. Together with the findings mentioned above, significant characteristics for clear differentiation of KMM $1406^{\mathrm{T}}$ from Rheinheimera baltica include its lack of blue-coloured pigmentation, presence of bipolar and lateral flagella, growth at $37^{\circ} \mathrm{C}$ and in $6-8 \% \mathrm{NaCl}$, positive reactions for aesculin hydrolysis, PNPG ( $p$-nitrophenyl $\alpha$-D-glucopyranoside) test, arabinose and citrate utilization and inability to utilize D-glucose. It has been reported that $R$. baltica strains do not require $\mathrm{NaCl}$ for growth and that sodium ions stimulate their growth (Brettar et al., 2002). In the present study, we failed to grow $R$. baltica DSM $14885^{\mathrm{T}}$ without $\mathrm{NaCl}$, whilst strain KMM $1406^{\mathrm{T}}$ gave good growth on the same media. In addition, $\mathrm{NaCl}$ was not needed to support growth of KMM $1406^{\mathrm{T}}$. Major phenotypic differences of the new strain from the phylogenetically less related species $A$. fetalis were as follows: motility, inability to reduce nitrate or thiosulfate, lack of growth at 40 or $42{ }^{\circ} \mathrm{C}$ or without $\mathrm{NaCl}$, hydrolysis of some compounds and assimilation pattern (Table 1). On the basis of phenotypic characterization and phylogenetic analysis, we propose that strain KMM $1406^{\mathrm{T}}$ should be classified as a novel species, Rheinheimera pacifica sp. nov., with the type strain $\mathrm{KMM} 1406^{\mathrm{T}}\left(=\mathrm{JCM} 12090^{\mathrm{T}}=\right.$ NRIC $0539^{\mathrm{T}}=$ CCUG $46544^{\mathrm{T}}$ ). 


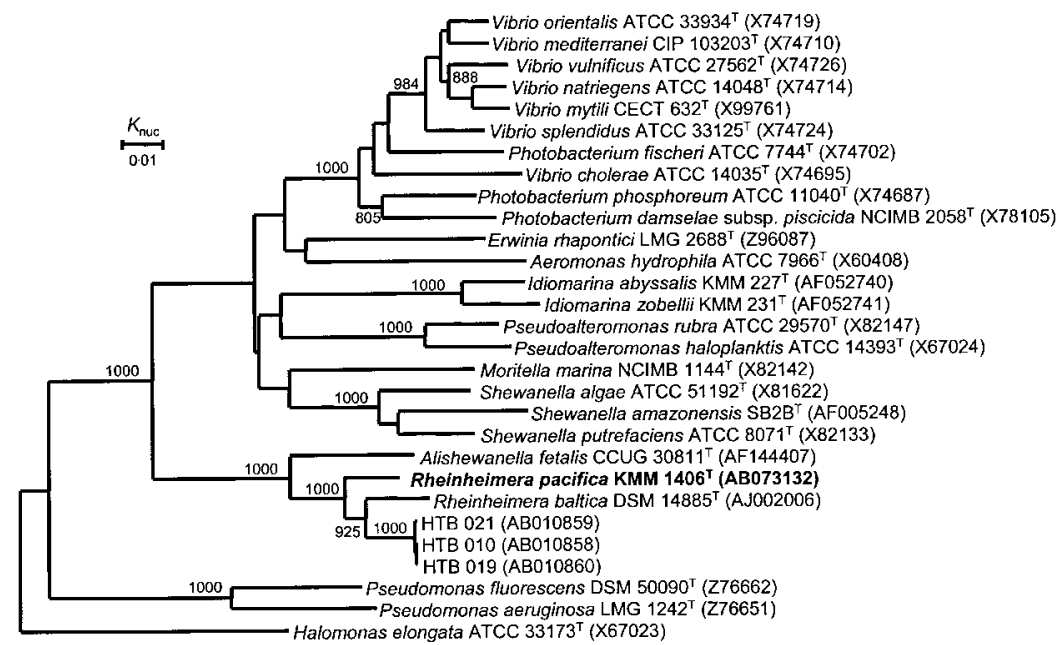

Fig. 2. Phylogenic relationships of $\mathrm{KMM}$ $1406^{\top}$ and some related genera, based on 16S rRNA gene sequences. The branching pattern was generated by the neighbourjoining method. Significances for particular nodes were obtained by bootstrap analysis. GenBank accession numbers are given in parentheses. Bar, 0.01 nucleotide substitution per site.

\section{Description of Rheinheimera pacifica sp. nov.}

Rheinheimera pacifica (pa.ci'fi.ca. N.L. fem. adj. pacifica from the Pacific Ocean, pertaining to the Pacific Ocean sea-water sample from which the type strain was isolated).

Strictly aerobic, Gram-negative, chemoheterotrophic, oxidaseand catalase-positive, rod-shaped, $1 \cdot 8-2 \cdot 0 \mu \mathrm{m}$ long and $0 \cdot 6-0 \cdot 8 \mu \mathrm{m}$ wide and motile with four to seven polar or bipolar and lateral flagella. Sodium ions are not required for growth. Growth is observed in $0-8 \%(\mathrm{w} / \mathrm{v}) \mathrm{NaCl}$, but not in $10 \% \mathrm{NaCl}$. Grows at $4-37^{\circ} \mathrm{C}$, but not at $40-41^{\circ} \mathrm{C}$. Non-pigmented, smooth, transparent and circular colonies with entire margins are formed on MA. Gelatin, starch, casein, Tween 80 and DNA are hydrolysed. Glucose fermentation and $\mathrm{H}_{2} \mathrm{~S}$ production are not detected. Glycerol, acetate, L-arginine, valine, asparagine and DL-lysine are utilized, but methionine and L-glutamic acid are not. According to the API 20NE test (bioMérieux), aesculin and gelatin hydrolysis, PNPG test, arabinose, $\mathrm{N}$-acetylglucosamine, maltose and citrate assimilation are positive and the following tests are negative: nitrate reduction, indole production, arginine dihydrolase, urease and assimilation of glucose, mannose, mannitol, gluconate, L-malate, caprate, adipate and phenylacetate. Assimilation of trehalose and sucrose is positive. In API ZYM analysis, positive reactions are exhibited for alkaline phosphatase, esterase $\mathrm{C} 4$, esterase lipase C8, leucine arylamidase, trypsin, $\alpha$-chymotrypsin, naphthol-AS-BI-phosphohydrolase and $N$-acetyl- $\beta$-glucosaminidase; negative reactions are exhibited for lipase C14, valine arylamidase, cystine arylamidase, acid phosphatase, $\alpha$-galactosidase, $\beta$-galactosidase, $\beta$-glucuronidase, $\alpha$-glucosidase, $\beta$-glucosidase, $\alpha$-mannosidase and $\alpha$-fucosidase. Susceptible to gentamicin $(10 \mu \mathrm{g})$; weakly susceptible to polymyxin $(300 \mathrm{U})$, streptomycin $(30 \mu \mathrm{g})$, kanamycin $(30 \mu \mathrm{g})$ and neomycin $(15 \mu \mathrm{g})$ and resistant to carbenicillin $(25 \mu \mathrm{g})$, lincomycin $(15 \mu \mathrm{g})$, oleandomycin $(15 \mu \mathrm{g})$, tetracycline $(30 \mu \mathrm{g})$, ampicillin $(10 \mu \mathrm{g})$ and benzylpenicillin $(10 \mathrm{U})$. DNA G $+\mathrm{C}$ content of the type strain is $49.6 \mathrm{~mol} \%$ (determined by the thermal denaturation method). Predominant cellular fatty acids are $\mathrm{C}_{16: 0}, \mathrm{C}_{17: 0}, \mathrm{C}_{16: 1} \omega 9 c$,
$\mathrm{C}_{17: 1} \omega 8 c$ and $\mathrm{C}_{18: 1} \omega 7 c$. Fatty acids $\mathrm{C}_{15: 0}, \mathrm{C}_{15: 1} \omega 8 c, \mathrm{i}-\mathrm{C}_{16: 0}$ and $\mathrm{i}-\mathrm{C}_{18: 0}$ are minor components.

The type strain, KMM $1406^{\mathrm{T}}\left(=\mathrm{IAM} 15043^{\mathrm{T}}=\mathrm{JCM}\right.$ $12090^{\mathrm{T}}=$ NRIC $0539^{\mathrm{T}}=$ CCUG $\left.46544^{\mathrm{T}}\right)$, was isolated from deep sea water of the Pacific Ocean.

\section{Acknowledgements}

The authors are grateful to Dr Ingrid Brettar for the gift of Rheinheimera baltica DSM $14885^{\mathrm{T}}$. We thank Dr Kazuo Komagata for helpful discussion. This study was supported by grant no. 02-0449517 from the Russian Foundation for Basic Research and by grant no. 95-01/03-19 from the Russian State Committee for Science and Technologies.

\section{References}

Brettar, I., Christen, R. \& Höfle, M. G. (2002). Rheinheimera baltica gen. nov., sp. nov., a blue-coloured bacterium isolated from the central Baltic Sea. Int J Syst Evol Microbiol 52, 1851-1857.

Fonnesbech Vogel, B., Venkateswaran, K., Christensen, H., Falsen, E., Christiansen, G. \& Gram, L. (2000). Polyphasic taxonomic approach in the description of Alishewanella fetalis gen. nov., sp. nov., isolated from a human foetus. Int J Syst Evol Microbiol 50, 1133-1142.

Leifson, E. (1963). Determination of carbohydrate metabolism of marine bacteria. J Bacteriol 85, 1183-1184.

Marmur, J. \& Doty, P. (1962). Determination of the base composition of deoxyribonucleic acid from its thermal denaturation temperature. J Mol Biol 5, 109-118.

Owen, J., Hill, L. R. \& Lapage, S. P. (1969). Determination of DNA base compositions from melting profiles in dilute buffers. Biopolymers 7, 503-516.

Shida, O., Takagi, H., Kadowaki, K., Nakamura, L. K. \& Komagata, K. (1997). Transfer of Bacillus alginolyticus, Bacillus chondroitinus, Bacillus curdlanolyticus, Bacillus glucanolyticus, Bacillus kobensis, and Bacillus thiaminolyticus to the genus Paenibacillus and emended description of the genus Paenibacillus. Int J Syst Bacteriol 47, 289-298.

Smibert, R. M. \& Krieg, N. R. (1994). Phenotypic characterization. In Methods for General and Molecular Bacteriology, pp. 607-655. 
Edited by P. Gerhardt, R. G. E. Murray, W. A. Wood \& N. R. Krieg. Washington, DC: American Society for Microbiology.

Stackebrandt, E. \& Goebel, B. M. (1994). Taxonomic note: a place for DNA-DNA reassociation and 16S rRNA sequence analysis in the present species definition in bacteriology. Int J Syst Bacteriol 44, 846-849.
Svetashev, V. I., Vysotskii, M. V., Ivanova, E. P. \& Mikhailov, V. V. (1995). Cellular fatty acids of Alteromonas species. Syst Appl Microbiol 18, 37-43.

Takami, H., Kobata, K., Nagahama, T., Kobayashi, H., Inoue, A. \& Horikoshi, K. (1999). Biodiversity in deep-sea sites located near the south part of Japan. Extremophiles 3, 97-102. 